\title{
Community Capacity for Implementing Clean Development Mechanism Projects Within Community Forests in Cameroon
}

\author{
Peter A. Minang $\cdot$ Michael K. McCall $\cdot$ \\ Hans Th. A. Bressers
}

Received: 29 August 2006/ Accepted: 20 October 2006

(C) Springer Science+Business Media, LLC 2007

\begin{abstract}
There is a growing assumption that payments for environmental services including carbon sequestration and greenhouse gas emission reduction provide an opportunity for poverty reduction and the enhancement of sustainable development within integrated natural resource management approaches. Yet in experiential terms, community-based natural resource management implementation falls short of expectations in many cases. In this paper, we investigate the asymmetry between community capacity and the Land Use Land Use Change Forestry (LULUCF) provisions of the Clean Development Mechanism within community forests in Cameroon. We use relevant aspects of the Clean Development Mechanism criteria and notions of "community capacity" to elucidate determinants of community capacity needed for CDM implementation within community forests. The main requirements are for community capacity to handle issues of additionality, acceptability, externalities, certification, and community organisation. These community capacity requirements are further used to interpret empirically derived insights on two community forestry cases in Cameroon. While local variations were observed for capacity requirements in each case, community capacity was generally found to be insufficient for meaningful uptake
\end{abstract}

P. A. Minang $(\square) \cdot$ M. K. McCall

International Institute for Geo-Information Science and Earth Observation (ITC), P.O. Box 6, 7500 AA, Enschede, Netherlands

e-mail: minang@itc.nl

H. Th. A. Bressers

Centre for Clean Technology and Environmental Policy (CSTM), University of Twente, P.O. Box 217, 7500 AE, Enschede, The Netherlands and implementation of Clean Development Mechanism projects. Implications for understanding factors that could inhibit or enhance community capacity for project development are discussed. We also include recommendations for the wider Clean Development Mechanism/ Kyoto capacity building framework.

Keywords Community capacity · Clean Development Mechanism - Community forests · Cameroon

\section{Introduction}

There is a growing assumption that payments for environmental services including carbon sequestration and greenhouse gas emission reduction could provide an opportunity for poverty reduction and the enhancement of sustainable development within integrated natural resource management approaches (Asquith and others 2002; Pagiola and others 2005). Studies have identified community forest management as a model that could meet the triple objectives of providing mechanisms and incentives for community management of carbon, forest conservation and local development needs (Klooster and Masera 2000; Poffenberger and others 2002; Smith and Scherr 2003). Yet community-based natural resource management performance remains mixed (Agrawal 2001; Armitage 2005; Barrett and others 2005). This study seeks to find out whether or not and in what ways communities currently managing forests in Cameroon meet the capacity requirements to handle the Clean Development Mechanism (CDM) projects.

The CDM is one of three "flexible mechanisms" in the Kyoto Protocol designed to accomplish the 
objectives of the UNFCCC. It makes provision for investment by industrialised countries and industry in projects related to carbon emissions reduction and carbon sequestration in developing countries. These projects should contribute to sustainable development in developing countries (i.e., Non-Annex 1 countries) while enabling developed countries (i.e., Annex 1 countries with quantified emission reduction targets) to meet the Kyoto emission reduction and quantified emission limitation targets (Art. 12.2 of the Kyoto Protocol).

Land Use Land Use Change and Forestry (LULUCF) and energy projects are required to meet certain conditions in order to acquire Certified Emission Reductions from the Executive Board of the CDM. Main conditions include additionality (mitigation effects "with project" must be additional to what would have happened "without project"); leakage (project mitigation effects must not be offset by project impacts outside the accounting boundary); and contribution to sustainable development (to be demonstrated according to host country rules). Certified Emission Reductions represent the emission reduction or sequestration output of a project, and constitute the basis on which payments are made.

Brown and others (2000) state that current modalities and information requirements for $\mathrm{CDM}$ are beyond the scope of community capabilities and skills. However, few studies have attempted to test the dimensions of this alleged asymmetry between CDM modalities and procedures and local community capabilities and skills. In this paper, we seek to review this gap by examining local community capacity for the development and implementation of CDM projects within Community Forests in Cameroon.

We use conceptual notions of CDM criteria and community capacity to empirically analyse two community forestry cases in Tinto and Bimbia Bonadikombo, Cameroon. The intention is to identify, document, and interpret local strategies and conditions affecting past community forestry successes and failures, in order to recognise and understand those factors that might enhance or limit community capacity for CDM implementation.

The paper is structured as follows. Section 2 highlights the criteria and conditions for CDM projects and the main features of community forestry in Cameroon. Appropriate community capacity requirements for CDM projects are derived in section 3 . Section 4 presents the methods used and the study context. In section 5 , we evaluate community capacity and draw implications for $\mathrm{CDM}$ and the wider $\mathrm{CDM} / \mathrm{Kyoto}$ policy framework.
By "community" is meant certain characteristics referred to in community-based natural resource management including, having reasonably defined decision-making processes; being a homogenous unit (sometimes ethnic) with shared goals and values; having traditional resource use systems and livelihood strategies; and also having a clear spatial or conceptual boundary (Armitage 2005; Li 2002). While these are good conceptual characteristics to work with, Li (2002) sees these as very "strategic simplifications." In many instances, there is no crisp boundary between the state and the community, communities are not homogenous, having many individuals or groups that do not share community resource management goals. Property rights and decision-making systems may not also be as defined. We thus attempt to reflect these in our discussions.

We, therefore, see community capacity as the collective ability of individuals and groups acting in concert toward sustainable development in a given locality. In operational terms, community forests in Cameroon are managed by legal entities or community-based organisations constituted by a given "community" for the purpose. But first, we present the requirements for CDM forestry projects and community forestry modalities in Cameroon.

\section{CDM Requirements and Community Forestry}

\section{CDM Requirements}

CDM projects are expected to meet a set of requirements prior to the issuance of certified emission reductions by the CDM Executive board. These requirements are articulated in the Kyoto Protocol and in subsequent decisions taken during the Conference and Meetings of Parties (mainly in Decisions 19/ CP. 9 and 14/CP.10 and the Marrakech Accords). These requirements can be summarised under the following categories: additionality, acceptability, externalities, and certification.

It suffices to mention that these rules apply to afforestation and reforestation. These two are the only land use land use change and forestry activities accepted under the CDM.

\section{Additionality}

Sequestration or emission reductions due to the project activities must be "additional" to any that would occur in the absence of the project (Paragraphs 18-22 of Decision 19/CP.9). In other words, additionality implies that projects must result in a net storage of 
carbon and, therefore, a net removal of carbon from the atmosphere. Other forms of additionality include programme, financial, and investment additionality. Programme additionality refers to project demonstration that its emission reductions are additional to emissions required by law or government policy. Financial additionality refers to the fact that funding for the implementation of projects must not come from overseas development or environment assistance funds. Investment additionality refers to the demonstration that the creation of carbon offsets will involve costs that would not be incurred in the "business as usual" scenario. Though not a requirement per se, it is a way of demonstrating "intent" and effort through financial analysis.

\section{Acceptability}

The Kyoto Protocol states that all carbon offset projects in developing countries are required to contribute to sustainable development (Article 2.1 and 12.2). Host countries have to have criteria for sustainable development by which projects will be judged. In addition, projects must be consistent with other international agreements and guidelines such as the Convention on Biodiversity, Agenda 21, Ramsar, and others.

\section{Externalities (Environmental Impact and Leakage)}

Projects must demonstrate a clear strategy to deal with all impacts/effects that may arise from project implementation. These impacts could include positive or negative social, cultural, economic, or environmental impacts. Projects have to show how the negative impacts would be mitigated or countered.

A prominent aspect in externalities is the question of leakage. Leakage can be defined as unplanned emissions that could occur outside project boundaries as a result of project activities. Leakage should not disqualify a project except in instances where projections of emissions are substantial enough to negate projected carbon offsets. However, project analysis must show how leakage has been estimated and what measures will be put in place to minimize it.

\section{Certification}

The concreteness, measurability, and long-term characteristics of the project will have to be checked independently by a third-party (i.e., a Designated Operational Entity) accredited by the CDM executive board. This takes place in three stages during the CDM project cycle namely validation, verification, and certification.
Validation is the process of independent evaluation of project activity based on the Project Design Document against the CDM requirements. The outcome is the registration of the project.

Verification is the independent review process of monitored reductions or sequestration that occurred as a result of a registered project activity for a given period. This is an ex-post check to confirm whether or not and to what extent carbon offsets have actually been attained.

Certification is the process by which the designated operational entity gives written assurance of the emission reductions or sequestrations achieved by the project during a specified time period as verified. The result is the issuance of Certified Emissions Reductions (CERs).

\section{Small-Scale Afforestation and Reforestation Projects}

Following discussions on the complications and costs involved in responding to the rules or requirements outlined above, baseline, monitoring, and certification modalities were simplified for "small-scale projects." Decision 14/CP.10 defines small-scale projects as those that will result in net anthropogenic greenhouse gas removals by sinks of less than 8 kilo tonnes of carbon dioxide per year during the crediting period. However, the host country has to approve that the project developers are a low-income community or individuals.

\section{Community Forests}

Many authors have argued that community forest management has the potential of fulfilling the triple objectives of biodiversity conservation, supporting local development, and providing forest services such as carbon sequestration (GEF 2000; Klooster and Masera 2000; Smith and Scherr 2003). Hence, if well managed, it could contribute substantially to the achievement of CDM objectives.

Furthermore, the area of forests under various forms of community management has been increasing in the world. White and Martin, (2002) note that $14 \%$ of forests in the most forested countries are owned by communities, whilst some $8 \%$ more are controlled by communities. More forests in Cameroon are coming under community management following new forest legislation in 1994, introducing community forestry. By January 2006, there were 334 applications by communities in the Ministry of Forests and Fauna (MINFOF). Of the 334 applications, 90 community forests were under full community management, indicating that the 
figure more than quadrupled from 17 in December 2001. At this rate, total area under community forestry could attain 1 million hectares in five years (i.e., 200 community forests at a maximum of 5000ha).

Community forestry in Cameroon was chosen for this study because the policy provisions for community forestry provides a good institutional and regulatory framework (though not sufficient) for project appraisal, approval and verification by the Sub-Directorate of community forestry in the Ministry of Forests and Fauna (Minang and others 2007). Rules and regulations are elaborated in the Manual of Procedures and Norms for the Management of Community Forests (MINEF 1998). No other forest management type in Cameroon has such a regulatory framework. We briefly present the concept of community forestry in Cameroon in the following paragraphs.

Community Forest is defined as "that part of nonpermanent forest estate (not more than 5000ha) that is the object of an agreement between government and a community in which communities undertake sustainable forest management for a period of 25 years renewable" (MINEF 1998).

Government approves a community forest application and signs a management agreement upon community fulfilment of the following requirements,

- The community has constituted a legal entity and appointed a community forest manager who shall represent them in negotiations with government in matters of community forestry;

- The community has delineated and mapped the intended community forest area;

- The community has completed an $8-10 \%$ inventory of the timber, non-timber forest products, and wildlife of the forest;

- The community has provided a description of previous activities carried out in the intended forest area;

- The community presents a simple management plan for the intended forest; and

- The community shows proof of stakeholder agreement on the intentions of forest management.

Once the management agreement is signed, policy requirements are as follows:

- That $100 \%$ inventories are carried out in the compartments prior to the commencement of activities;

- The management of community forests provide annual activity plans for approval;

- The management of community forests provide annual reports to government; and
- The community forest management plans are reviewed every five years.

Many community forests in Cameroon are a mix of natural and secondary forests. Some cocoa agroforests are also found within community forests as well. Therefore, a broad spectrum of activities including regeneration, afforestation, logging, and non-timber forest product collection is implemented within community forests.

However, current CDM rules only accept afforestation and reforestation type forestry; therefore, natural forest management by communities is not eligible. But the possibility exists that forest management could be taken up by the Kyoto protocol in the future (post 2012) under different rules (Santili and others, 2005).

Private individuals, companies, or government own most current CDM projects institutions where decision-making and management are likely to have more structure and simplicity. Community ownership and management is complex and problematic in terms of resource tenure, project responsibilities, benefit allocation, and governance aspects. CDM rules have not been tested in those complex communities that harbour tremendous biosphere carbon management potential.

\section{Community Capacity Assessment Framework}

Project developers are required to put forth arguments and supporting evidence for each CDM requirement in a Project Design Document. Special knowledge, skills, technology, and infrastructure are also needed for collecting and analysing the required evidence. Furthermore, planning, coordination, and management skills will be required in the project development process.

In the ensuing paragraphs, we review specific tasks of each requirement in order to elucidate dimensions of community capacity requirements. Table 1 presents a summary of the resulting assessment framework of community capacity for CDM forestry projects.

Additionality: The draft tool for the demonstration of additionality proposes a five-step screening and analysis procedure for CDM projects including,

- Preliminary screening based on the starting date of the project activity and the specific features of the afforestation and reforestation activity (mapping and map analysis, land use analysis);

- Identification of alternatives to the project activity consistent with current laws and regulations (land 
use analysis, estimates/measurements of carbon stocks, projections, baseline development);

- Investment/financial analysis (Internal Rates of Return, Net Present Value, cost benefit ratio, sensitivity analysis, etc.)

- Barrier analysis (investment, institutional, technological, cultural, social, ecological, and other kinds of barriers); and

- Impact of CDM registration (Expected).

The above-mentioned steps are indicative of the knowledge and skills required to provide valuable arguments and evidence on additionality.

The draft tool for additionality also specifies that evidence regarding land use can be provided from land use and land cover maps and satellite images of around 1990. This means access to mapping technology as well as other technology for measurements of soil carbon or biomass estimation will be required. Lee (2004) concludes that most of the information is technical, requiring good knowledge and skills and technology to collect and manage.

It can be argued that communities may hire these services, but the costs can be very high. Recent studies in Tanzania revealed that costs for carbon inventories done by communities (with minimal supervision) would be 10 times, or more, cheaper than when experts are contracted (Zahabu 2006). Community inventory costs ranged between 2.5 and $21 \$ /$ ha/yr. Transaction costs for afforestation and reforestation have been estimated at between \$8-31/tC (Poffenberger and others 2002) and \$0-70/tC (de Jong and others 2000).

Eligibility: Demonstrating compliance with national sustainable development rules involves engagement with the national authorities and providing evidence. For community forestry in Cameroon, "sustainability" implies creating a legal entity, ensuring participation, developing a simple management plan, and developing a benefit sharing mechanism. Technical expertise and resources (financial and material) are thus required to provide the evidence.

Externalities: Environmental impact assessments and social impact assessments are required of each project. The project is also required to show how they will mitigate or solve any negative impacts identified by studies. The same holds for leakage. Relevant knowledge and skills as well as resources are thus required to carry out these studies and design mitigation measures.

Certification: A monitoring plan must be provided for all the variables estimated in the project design document. This requires a demonstration of how information would be collected and archived to enable validation and verification by the designated opera- tional entity. The data collection, processing, storage, retrieval, and sharing with the operational entities demand a certain level of data and information infrastructure. The term data or information infrastructure means the relevant base collection of technologies, policies, and institutional arrangements that facilitate the availability of and access to data relevant for the implementation of carbon forestry.

Negotiations, contracting services, and communication with the operational entities involve costs and specific skills. Ecosecurities (2002) estimates the costs of validation at between $\$ 18,900$ and $\$ 37800$ and verification costs at about $\$ 9400$ per audit. Prototype Carbon Fund cost estimates are slightly higher (Lee 2004).

Management Capabilities and Conditions: Though not a direct CDM requirement, management remains a critical success factor for CDM projects, hence it is being incorporated by operational entities in validation processes. Nelson and de Jong (2003) demonstrate the importance of institutional arrangements in rule setting, enforcement, and monitoring for carbon forestry projects in Chiapas, Mexico. Poffenberger and others (2002) cite interalia, effective institutions, democratic leadership, transparency in decision-making and public expenditures, and minimizing social conflicts as important success factors for community carbon forestry. Subak (2000) also underscores the role of governments and NGOs in providing technical and institutional support for carbon mitigation projects in Costa Rica. FERN (2000) reported conflicts resulting from resource tenure perceptions that created serious problems for a carbon project in East Africa.

Based on the preceding paragraphs, we raise key questions for community capacity assessment under the four CDM requirements. We also include a category on Management capabilities and conditions-see Table 1 (Ivey and others 2004). The various issues discussed in this framework are interrelated; hence, we try to show these interactions as much as possible based on our empirical evidence.

\section{Methods and Context}

\section{Methods}

This study aims at evaluating community capacity to meet CDM conditions. To do so, we create a framework (Table 1) and seek empirical evidence by way of case studies. We identified two communities in Cameroon for the study: Tinto and Bimbia Bonadikombo (hereinafter called Bimbia). The choice of these 
Table 1 CDM community capacity assessment framework

\begin{tabular}{ll}
\hline CDM requirement & Community Capacity requirements \\
\hline Additionality & $\begin{array}{l}\text { Does the community have access to adequate financial resources for baseline and other analysis? } \\
\text { Does community have access to required technology for data collection and analysis? } \\
\text { Does community have access to necessary human resources (knowledge and skills)? }\end{array}$ \\
Acceptability & $\begin{array}{l}\text { Are the necessary national sustainable development policy analysis knowledge and skills available within the } \\
\text { community? }\end{array}$ \\
Externalities & Are the necessary impact assessment and leakage analysis knowledge and skills available within the \\
& community? \\
Certification & How adequate is the community forest monitoring system? \\
& How adequate is the community information infrastructure? \\
& Is the relevant CDM information (forest inventory, socio-economic) available? \\
Management & Are actors effectively participating in decision-making and implementation? \\
Capability & How effectively are resource rules being implemented? \\
& How good are actor relationships in forest management? \\
& Are communities receiving adequate government and NGO support?
\end{tabular}

communities was based on the willingness to provide data and the relative homogeneity/heterogeneity and accessibility of the communities. All three villages in Tinto and four villages in Bimbia are typical small rural livelihood-based settings, while two settlements in Bimbia are relatively larger and peri-urban. The fact that these cases were not initially conceived for CDM purposes constitutes a limitation in the study.

Data collection tools included semi-structured interviews (19), structured-interviews/questionnaires (84), focus group discussions (6), secondary data review, and forest transect walks. Given the substantive nature of the dimensions of community capacity, more discursive data collection tools were selected (Frankfort-Nachmias and Nachmias 1996; Yin 1994). Questionnaires were used for selected community resource persons to understand the relevant community knowledge and skills pool. Data sources included community forest legal entities, Ministry staff, traditional authorities, NGO staff, community/user groups, and municipal authorities. Documents analysed included various planning, monitoring, seizure, and study reports. Interviews were used to obtain insight and check the information from secondary sources and other tools. Thematic and issue based content analysis was used to analyse the transcripts and secondary information for answers to questions in the community capacity assessment framework.

\section{The Empirical Setting}

The Tinto community consists of three neighbouring villages of the same clan namely Bessinghe, Kerieh, and Mbu. The total population of between 1700-2000 is very homogenous with less than $1 \%$ "outsiders." It is typically rural, but is an administrative (District) headquarters with a forestry office. Most farmers grow cocoa or coffee as cash crops, alongside cassava, maize, and other subsistence crops. Forest activities include hunting, collecting non-timber forest products, and timber. Tinto began a community forest planning process in November 1999 and signed a management agreement with government for an evergreen lowland forest area of 1295 ha in December 2002. But little has happened by way of management to date.

The Bimbia Bonadikombo community is a complex of many villages namely, Mbonjo, Chopfarm, Banangombe, Bonabile, Dikolo, Mabeta, Ombe Native (Bamukong), Bonadikombo, and several plantation worker camps. Two of these settlements (Bonabile and Dikolo) are larger and peri-urban in character and located on the fringes of the Limbe (Victoria) town (see Fig. 1). Limbe and the surrounding areas have a population of about 123,900 inhabitants (RCDC 2002). It is highly heterogeneous with few local people (of the Bakweri tribe). Forest extraction activities in order of importance include collection of non-timber forest products, fuel wood and timber, charcoal burning and hunting. The community has been managing a 3700-ha forest since mid 2002. Vegetation is evergreen with different types: littoral vegetation, mangrove, freshwater swamp forest, stream and riverside vegetation, and lowland rainforest.

\section{Community Forest Actors}

A nested institutional structure can be observed in both the Tinto and Bimbia communities. There are user groups, community-based organisations created for community forest management purposes, and traditional authorities, all of which are moulded and developed within the locality. These organisations 


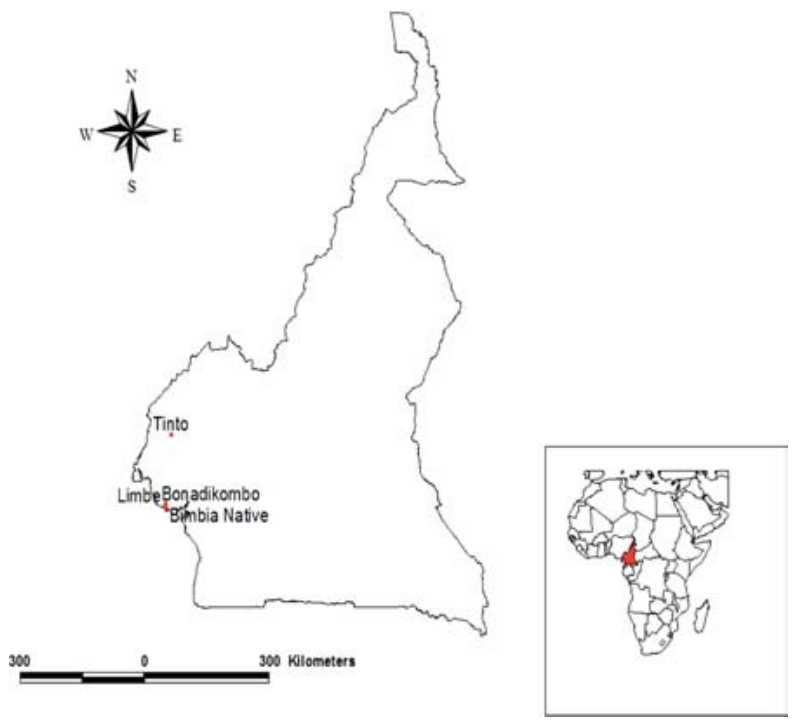

Fig. 1 Location of study areas in Cameroon

work closely with the forest administration and NGOs. Table 2 presents a summary of actors, their interests and responsibilities within community forests in these communities.

The makeup of institutional structures differs slightly between the two communities and some actors such as charcoal burners are only found in the Bimbia community. It is worth noting that forest use and livelihood activities often involve combinations of activities. But we present the actors in terms of forest use activities in order to capture specific issues that could otherwise be diluted in the analysis of various activity combinations.

\section{Assessing Community Capacity for CDM project development}

In this section, we evaluate community capacity in the light of CDM requirements and the corresponding community capacity requirements (Table 1), including mainly additionality, acceptability, externalities, certification and management capabilities and conditions. (Table 5) provides a summary of the findings.

\section{Additionality}

The key additionality capacity question to address is whether or not communities have access to the financial, technological and human resources required to fulfil additionality requirements.

In terms of financial resources, total annual income in 2005 for Bimbia stood at $\$ 31,200$ (see Table 3). At the end of that year, Bimbia was running at a deficit of about $\$ 3000$. Total income in Tinto stood at $\$ 10,150$. One hundred percent of the reported income for Tinto during this period was an advance payment for timber exploitation. Prior to this deposit, all income for the Tinto community forest over three years was a grant from Living Earth amounting to $\$ 800$.

Considering mitigation potential and transaction costs for various averted deforestation, reduced impact logging and regeneration carbon scenarios as in Table 4, and the financial resources of both communities, the investment requirements will be extremely difficult if not impossible for these

Table 2 Summary description of community forestry actors

\begin{tabular}{|c|c|}
\hline Actor & Interests and Responsibility \\
\hline $\begin{array}{l}\text { 1. Bimbia Bonadikombo Natural Resource } \\
\text { Management Council (BBNRMC) }\end{array}$ & $\begin{array}{l}\text { Manages Bimbia forest; Has an elected Board and a Forest Management Officer } \\
\text { overseeing day-to-day operations }\end{array}$ \\
\hline $\begin{array}{l}\text { 2. Tinto Clan Community Forest-Common } \\
\text { Initiative Group (TCCF-CIG) }\end{array}$ & $\begin{array}{l}\text { Manages Tinto forest; Has an elected Management Committee and a Forest } \\
\text { Management Officer in charge of day-to-day operations. }\end{array}$ \\
\hline 3. Chiefs & $\begin{array}{l}\text { Village heads; custodians of forests; authorise access to all resources and land; in } \\
\text { both cases are members of the BBNRMC board and TCCF-CIG committee, } \\
\text { respectively }\end{array}$ \\
\hline 4. Forest User Groups & $\begin{array}{l}\text { Includes all user groups; interested in access rights; participate in general assemblies } \\
\text { of organisations; In the case of Bimbia, each user group has a representative on } \\
\text { the Board }\end{array}$ \\
\hline 5. Women in communities & Interested in access rights for non-timber forest products and farmland \\
\hline 6. Elites & $\begin{array}{l}\text { "Successful" sons and daughters living outside the community (as defined by these } \\
\text { communities): interested in broad village development; }\end{array}$ \\
\hline 7. Ministry of Forests and Fauna (MINFOF) & $\begin{array}{l}\text { Mandated to ensure sustainable forest management; provide technical support; } \\
\text { conflict resolution }\end{array}$ \\
\hline 8. Municipal Authorities & Interested in contributions of community forest to development of municipality \\
\hline 9. Non-Governmental Organisations (NGOs) & $\begin{array}{l}\text { Interested in sustainable forest management; provides technical, institutional, and } \\
\text { financial support; } \\
\text { Mount Cameroon Project supported Bimbia, while Living Earth Foundation } \\
\text { supported Tinto. }\end{array}$ \\
\hline
\end{tabular}


Table 3 Estimated income and expenditure of community forests (January-December 2005)

\begin{tabular}{|c|c|c|}
\hline Description & $\begin{array}{l}\text { Bimbia } \\
\text { Bonadikombo }\end{array}$ & Tinto \\
\hline \multicolumn{3}{|l|}{ Income } \\
\hline $\begin{array}{l}\text { Total } \\
\text { (XAF/USD) }\end{array}$ & $\begin{array}{l}14,867,000 / \\
30200\end{array}$ & $\begin{array}{c}5,000,000^{\mathrm{a}} / \\
10150\end{array}$ \\
\hline $\begin{array}{l}\text { From forest } \\
\text { operations- wood (\%) }\end{array}$ & 28.5 & 100 \\
\hline From grants/donations (\%) & 10.4 & 0 \\
\hline $\begin{array}{l}\text { From service delivery } \\
\text { (ecotourism and } \\
\text { tree care services to Urban } \\
\text { Council }(\%)\end{array}$ & 23 & 0 \\
\hline Fines and auction sales (\%) & 19.1 & 0 \\
\hline Loans $(\%)$ & 18.8 & 0 \\
\hline \multicolumn{3}{|l|}{ Expenditure } \\
\hline Total (XAF/USD) & $\begin{array}{l}15,910,000 / \\
32300\end{array}$ & $940,000 / 1900$ \\
\hline Operational costs, Office (\%) & 11 & 100 \\
\hline Operational costs, Field (\%) & 23.4 & 0 \\
\hline Salaries $(\%)$ & 62.8 & 0 \\
\hline Investments (\%) & 0 & 0 \\
\hline
\end{tabular}

${ }^{a}$ This amount represents a deposit made by a potential timber exploiter in November 2005, as proof of liquidity

communities without external support. Table 4 was calculated by using a chronosequence of mean carbon content and rates of carbon saved under different land use options in Cameroon. We estimated that the Bimbia forest could mitigate between 7-12.4 Kt C y ${ }^{-1}$ and the Tinto forest between 1.7-5.3 (see Table 4). With production potentials of less than $8 \mathrm{Kt} \mathrm{Co}_{2} \mathrm{y}^{-1}\left(2182 \mathrm{tC} \mathrm{y}^{-1}\right)$, both projects could qualify for small-scale CDM. This means they can reduce transaction costs by up to $50 \%$. Yet with the current financial situation, they are unlikely to meet the investment requirements.

Community forestry as practiced in both communities is multi-activity and can entail prohibitive negotiation costs (Smith and Scherr 2003). De Jong and others (2000) reported costs of participation, negotiation, and conflict prevention in the Scolel Te project in southern Mexico ranging from \$52-325/ha. Such costs and those to be incurred on impact prediction, validation, and verification are not part of the concessions on small-scale CDM projects, yet these costs in themselves could be prohibitive to CDM project uptake and development.

Secondly, an analysis of pre-2005 financial records in both communities revealed they received overseas development assistance for community forestry implementation (11.70\% of income for Bimbia and $100 \%$ for Tinto; Table 3). Because communities received overseas development assistance for completely different project purposes, they may become ineligible under the financial additionality criterion.

Technical resources such as satellite images, GPSs, and tree height measurement instruments would be helpful in providing information required for baseline estimation. None of these communities have direct access to satellite images or facilities to process them. Bimbia can access images through the GIS unit of nearby Mount Cameroon Botanic Gardens and Conservation Centre. But they have to pay for it. Access to free satellite data from the Internet would be difficult given the very weak connectivity services in the region. Bimbia has one GPS that can allow them to map current land use. Tinto has a compass that can be useful for inventories.

The human resources required for related additionality analysis is currently limited in both communities. Fourteen Bimbia and 11 Tinto community members received training on timber inventories during the process of developing the simple management plans. The main skills acquired included doing physiological measurements (tree heights, dbh), using the compass and or the GPS, tree identification, and laying out sample plots and transects. But the skills required for carbon estimation are more complex, including biomass estimation, using allometric equations, root biomass estimation, measuring trees of all diameters, destructive sampling, and so on. These technical carbon estimation skills are absent in both communities.

Skills for financial and investment analysis are absent in these communities. One of the staff in Bimbia has basic undergraduate course knowledge in cost-benefit analysis but this is not enough. The community would thus have to hire such services at high costs. In Tinto, no one had such skills and knowledge.

\section{Acceptability}

The main capacity question in the acceptability criterion is do communities have the knowledge and skills to provide evidence of project contribution to sustainable development? According to the current community forestry regulations, "sustainability" is demonstrated by the development of a simple management plan, a viable legal entity, a benefit-sharing mechanism, and planned community projects (MINEF 1998). Both communities fulfilled these conditions, thanks to previous financial and technical assistance from NGOs and projects (McCall and Minang 2005). Mount Cameroon Project helped Bimbia while Living Earth Foundation assisted Tinto. Hence, we can say 
Table 4 Projected carbon mitigation potential for community Forests

\begin{tabular}{|c|c|c|c|}
\hline & Without Project & With Project Scenario $1^{c}$ & With Project Scenario $2^{c}$ \\
\hline \multicolumn{4}{|l|}{ Tinto Community } \\
\hline Total area (ha) & 1295 & & \\
\hline Vegetation type & Natural forest & & \\
\hline Scenario description & Conversion & $\begin{array}{l}\text { Averted DEForestation } \\
\text { (ADEF)- Conservation }\end{array}$ & $\begin{array}{l}\text { Reduced Impact Logging } \\
\text { (RIL) }\end{array}$ \\
\hline Potential area (ha)/yr & & 7.77 & 52 \\
\hline Carbon gain $-\mathrm{tC}$ ha $^{-1 \mathrm{a}}$ & & 220 & 104 \\
\hline $\begin{array}{l}\text { Total carbon saving } \\
\left(\mathrm{Kt} \mathrm{C} \mathrm{y}^{-1}\right)^{\mathrm{b}}\end{array}$ & - & 1.7 & 5.3 \\
\hline \multicolumn{4}{|l|}{ Bimbia Community } \\
\hline Total area (ha) & 3714 & & \\
\hline Vegetation type & $\begin{array}{l}\text { Natural forest }(50 \%) \text { and } \\
\text { mixed cocoa farms and } \\
\text { secondary forests }(50 \%)\end{array}$ & & \\
\hline Scenario description & Conversion & $\begin{array}{l}\text { ADEF - Conservation of } \\
\text { natural forest/Conservation }+ \\
\text { regeneration } \\
\text { Conservation }+ \text { regeneration }\end{array}$ & $\begin{array}{c}\text { (RIL)/conservation } \\
+ \text { regeneration }\end{array}$ \\
\hline Potential area $(\mathrm{ha}) / \mathrm{Yr}$ & - & 11 (ADEF)/ 928 (Conservation) & 74 (RIL)/928 (Conservation) \\
\hline Carbon gain $-\mathrm{tC}$ ha $^{-1 \mathrm{a}}$ & - & $220\left(\mathrm{tC} \mathrm{ha}^{-1}\right) / 5 \mathrm{tC} \mathrm{ha}^{-1} \mathrm{y}^{-1}$ & $104 / 5 \mathrm{tC} \mathrm{ha}^{-1} \mathrm{y}^{-1}$ \\
\hline \multirow[t]{2}{*}{ Total carbon saving $\left(\mathrm{Kt} \mathrm{C} \mathrm{y}^{-1}\right)$} & - & $2.4 / 4.64$ & $7.7 / 4.64$ \\
\hline & & 7.04 & 12.34 \\
\hline
\end{tabular}

${ }^{a}$ Mean Annual Carbon gain values for various project scenarios are assumed from reported studies in Cameroon as follows: ADEF (Kotto-Same and others 1997), RIL (Justice and others 2001), and Regeneration (Palm and others 2000).

${ }^{\mathrm{b}}$ Total carbon savings are given as $\sum$ (Carbon gain $\times$ potential area)

${ }^{\mathrm{c}}$ General Scenario assumptions are:

- Secondary forests are made available for conservation and regeneration

- There will be no fires, droughts or disasters during the project lifetime

- Illegal logging will be minimal and not sufficient to significantly affect project

- Forest areas do not include roads, water bodies and minor human settlements

- Exercise of usufruct rights for subsistence purposes including fuel wood, and non timber forest product harvesting is unlikely to significantly affect carbon flows

that both communities adhere to the sustainable development criteria that exist.

However, problems may emerge if national sustainability criteria for CDM eventually include international environmental conventions.

\section{Externalities}

The key capacity question addressed below is do communities have the knowledge and skills for the required impact assessment and leakage analyses.

Five persons (three employees and two board members) in Bimbia have at least undergraduate knowledge and some experience of environmental and social impact assessments. This means they have a good chance of providing the evidence required by this criterion of the CDM. On the other hand, none of the Tinto members had any knowledge of environmental or social impact assessments. No respondent in both communities had any understanding of leakage.

\section{Certification}

Communities would have to collect, analyse, archive, and eventually share information with designated operational entities responsible for validation and verification. Hence, the key capacity questions for certification include, how functional are community forestry monitoring systems? How adequate are community information infrastructures? And do communities have enough financial resources to engage Designated Operational Entities for validation?

Monitoring and reporting mechanisms in both communities suffer serious inadequacies. Monitoring and reporting in Bimbia are characterised by monthly management council board meetings at the managerial level, and by forest patrols at an operational level, 186 patrols in 2005. These meetings and patrols result in reports. However, the patrols are for the most part erratic, triggered by tip-offs on illegal activity. In 2003, control posts or check points that could be manned for 24 hours were made at strategic outlets from the forest, 
Table 5 Summary of findings

\begin{tabular}{|c|c|c|}
\hline Requirement & Bimbia Bonadikombo & Tinto \\
\hline \multicolumn{3}{|l|}{ Additionality } \\
\hline $\begin{array}{l}\text { Access to } \\
\text { financial } \\
\text { resources }\end{array}$ & $\begin{array}{l}\text { Insufficient financial resources. Deficit of } \$ 3000 \text { in } 2005 \\
\text { accounts; Little experience with high interest loans; } \\
\text { Eligibility unlikely due to use of ODA funds in forestry } \\
\text { implementation }\end{array}$ & $\begin{array}{l}\text { Insufficient financial resources. Functioning for past three } \\
\text { years with } \$ 784 \text { in total; No experience with loans; } \\
\text { Eligibility unlikely due to use of ODA funds in forestry } \\
\text { development. }\end{array}$ \\
\hline $\begin{array}{l}\text { Knowledge } \\
\text { and skills }\end{array}$ & $\begin{array}{l}\text { Limited knowledge and skills. One person with } \\
\text { undergraduate knowledge of cost benefit analysis and } \\
\text { none in investment or financial analysis methods. } \\
\text { Fourteen employees have knowledge and skills in } \\
\text { timber inventories only. }\end{array}$ & $\begin{array}{l}\text { Knowledge and skills are extremely limited. No } \\
\text { knowledge or experience of financial or investment } \\
\text { analysis in community. Eleven people have knowledge } \\
\text { and skills in timber inventories only. }\end{array}$ \\
\hline $\begin{array}{l}\text { Access to } \\
\text { technology }\end{array}$ & $\begin{array}{l}\text { Little or no access to satellite data and other technologies } \\
\text { required. }\end{array}$ & Same as in Bimbia \\
\hline \multicolumn{3}{|c|}{ Toquiter. } \\
\hline $\begin{array}{l}\text { Knowledge } \\
\text { and Skills }\end{array}$ & $\begin{array}{l}\text { Community fulfilled "sustainability" criteria in the } \\
\text { development of management plans with NGO support. } \\
\text { Hence have some relevant experience. }\end{array}$ & Same as in Bimbia \\
\hline \multicolumn{3}{|c|}{ 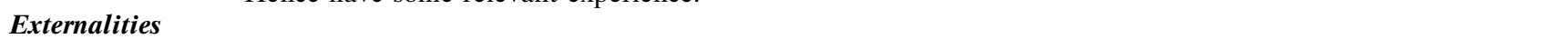 } \\
\hline \multirow[t]{2}{*}{$\begin{array}{l}\text { Environmental } \\
\text { impact and } \\
\text { leakage }\end{array}$} & $\begin{array}{l}\text { Three members in community have knowledge skills and } \\
\text { experience in environmental and social impact } \\
\text { assessment, therefore good potential }\end{array}$ & $\begin{array}{l}\text { No knowledge or skills in environmental or social impact } \\
\text { assessment observed }\end{array}$ \\
\hline & No knowledge or understanding of leakage observed & Same as in Bimbia \\
\hline \multicolumn{3}{|c|}{ 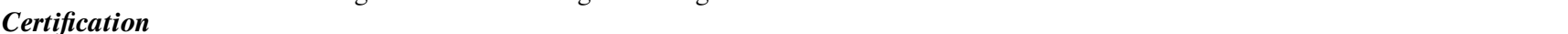 } \\
\hline $\begin{array}{l}\text { Monitoring } \\
\text { systems }\end{array}$ & $\begin{array}{l}\text { Monitoring systems are functional, but inadequate for } \\
\text { CDM because they do not involve ongoing inventories; } \\
\text { Short of manpower (ratio of staff to forest area is 1:285 } \\
\text { ha) }\end{array}$ & $\begin{array}{l}\text { No documented evidence of monitoring. The lone staff } \\
\text { cannot ensure any proper monitoring for an area of } \\
1 \text { 295ha. }\end{array}$ \\
\hline $\begin{array}{l}\text { Information } \\
\text { system }\end{array}$ & $\begin{array}{l}\text { Both physical and digital Information systems } \\
\text { (computers) are operational. This can allow for } \\
\text { "sharability"; hence, the system is potentially } \\
\text { adaptable to CDM archiving requirements. }\end{array}$ & $\begin{array}{l}\text { Information system consists of two cardboard folders. } \\
\text { Hence, inadequate in form, content, and quality for } \\
\text { CDM purposes. }\end{array}$ \\
\hline $\begin{array}{l}\text { CDM } \\
\text { Information } \\
\text { availability }\end{array}$ & $\begin{array}{l}\text { Some relevant geographical, socio-economic, ecological, } \\
\text { and general information is available for CDM use } \\
\text { within current systems. But much more is required }\end{array}$ & Same as in Bimbia \\
\hline $\begin{array}{l}\text { Financial } \\
\text { resources }\end{array}$ & $\begin{array}{l}\text { Inadequate financial resources to pay for validation } \\
\text { services }\end{array}$ & Same as in Bimbia \\
\hline \multicolumn{3}{|c|}{ Management Capability } \\
\hline $\begin{array}{l}\text { Actor } \\
\text { relationships }\end{array}$ & $\begin{array}{l}\text { Conflicts exist, (i) between } 6 \text { chiefs and management } \\
\text { board of community forest; (ii) between } \\
\text { community-MINFOF over } 14 \text { permits and proceeds } \\
\text { from auctioning of seizures; and (iii) between farmers } \\
\text { and forest management. }\end{array}$ & Conflicts between 3 chiefs and management officer. \\
\hline $\begin{array}{l}\text { Forestry rules } \\
\text { enforcement }\end{array}$ & $\begin{array}{l}\text { Illegal activity income accounts for about } 67 \% \text { of income } \\
\text { from legal forest activities and } 19 \% \text { of total revenue in } \\
2005 \text {. It is significant and poses threats to the success of } \\
\text { potential carbon project. }\end{array}$ & No illegal activity observed. Rules are being respected. \\
\hline $\begin{array}{l}\text { Government } \\
\text { community } \\
\text { relationship }\end{array}$ & $\begin{array}{l}\text { Government short of forestry personal (staff to forest } \\
\text { area ratio in the province is about 1:1500ha); } \\
\text { Government staff do not understand the CDM and } \\
\text { have no relevant skills to support communities }\end{array}$ & Same as in Bimbia \\
\hline $\begin{array}{l}\mathrm{NGO-} \\
\text { community } \\
\text { relationship }\end{array}$ & $\begin{array}{l}\text { The Cameroon Mountain Conservation Foundation } \\
\text { (CAMCOF) is interested in providing support for } \\
\text { carbon forestry in the area, but lack the knowledge, } \\
\text { skills and resources. }\end{array}$ & $\begin{array}{l}\text { Living Earth Foundation is interested in providing } \\
\text { support for carbon forestry in the community, but lacks } \\
\text { the knowledge, skills and resources. }\end{array}$ \\
\hline
\end{tabular}

but were later abandoned by the operation committee members. It is alleged that the control posts system did not give the room for corrupt practices desired by some operation committee members, hence, the abandonment. Some of them negotiate and collect fines from defaulters without the knowledge of the management officer. In extreme cases, they cooperate with illegal timber exploiters. In the case of Tinto, no monitoring or reporting of any sort has been done since December 2002 when the management agreement was signed. 
The community explains that with "zero" activities in the community forest, there is no reason to report. Given that these monitoring systems were not meant for CDM projects, they would need to be overhauled if these projects are to be registered within the CDM. However, the corruption and institutional planning problems currently experienced would still pose serious difficulties for CDM monitoring.

Neither community has conducted post-management agreement forest surveys or inventories of designated exploitation compartments as required by law. They have equally failed to convene general assemblies of stakeholders to discuss and review progress as their statutes demand since the commencement of community forest activities.

Community information systems were found in both cases to have relevant biophysical, socio-economic, and market data that could be used for further analysis on impact, baselines, leakage, and other CDM requirements. However, inventory data available to these community forests are inadequate for carbon estimation as they were done for timber exploitation as required by extant community forestry rules. Most of these studies were done with the help of NGOs prior to the management agreement. As demonstrated in the preceding text, further collection of complementary data for CDM without such assistance may be less reliable because communities do not have adequate skills.

Material and technological resources (infrastructure) can tremendously influence project information management. Bimbia currently has limited office space within the premises of the Divisional Office for Limbe. They have four operational computers and a digital filling system for all reports. Hard copies of reports are stored on shelves totalling about four metres in length. With a motorbike, 12 staff and little funds to hire cars regularly, transportation is a serious hindrance to monitoring efforts. In Tinto, activities are run from the forest manager's house. All information for the Tinto community forest is found in two cardboard folders.

\section{Management Capability and Conditions}

In this section, we examine the extent to which community decision-making processes, rules compliance, actor relationships, and relationships with government and NGOs are adequate for carbon project development.

\section{Participation and Decision-making}

Involving actors in building consensus and decisionmaking for CDM project implementation is important for local communities (de Jong and others 2000; Smith and Scherr 2003). Participation in decision-making is largely by actor representation in the decision-making bodies within the legal entities managing the forests on behalf of the communities. The management board in Bimbia is made up of chiefs, elected user group representatives, and some employees such as the forest manager. It meets on average 10 times a year. Attendance sheets show charcoal burners as the only consistent user group participating at these meetings. Timber exploiters and the fuel wood harvesters have been persistently absent. Latent power struggles within the leadership have weakened decision-making processes. The six chiefs in Bimbia sent a letter to the acting forest manager complaining that they were not being sufficiently consulted on day-to-day forest management issues such as issuance of permits (Letter of January 2005).

In Tinto, the management committee is made of all three chiefs, village representatives, and the forest manager. It has met about five times since December 2002. Interviewees reported about four ad hoc meetings between the manager, two chiefs, and one board member for consultation on proposals for sale of standing volume within the community forest between 2003 and 2005. Power struggles over money have also weakened decision-making in Tinto. All three chiefs in Tinto complain of not being consulted by the manager especially on financial issues. Given observed actor reactions and comments during informal discussions, it is our reasoned judgement that this is an important issue, which contributed to the inertia in the take off of community forestry activities in Tinto. These systems still harbour many weaknesses that may inhibit consensus-building processes for carbon forestry.

Annual general assemblies in which popular community participation is expected have not been convened in either case since mid-2002, implying that actors have not had the opportunity to participate in more strategic decision-making in community forestry.

\section{Implementation of Community Forestry Rules}

An assessment of community forestry rules compliance produced mixed results. In Bimbia, annual legal timber exploitation has been between 500 to $700 \mathrm{~m}^{3}$. About 5000 trees have been planted in two of three compartments envisaged in the management plan. There has also been good cooperation with charcoal burners in the implementation of management rules.

However, in Bimbia the rules have also been seriously flouted. Deforestation and degradation has been accelerated by farming and illegal timber exploi- 
tation. Illegal fuel wood harvesting is rife in the accessible southeast and western compartments of the forest. For example, in 2005, 186 forest monitoring patrols were conducted. During these patrols, the following were confiscated, 49 chain saws, $2000 \mathrm{~kg}$ of charcoal (100 bags of about $100 \mathrm{~kg}$ ), 301 small fuel wood chunks, and 1254 sawn timber boards of various sizes $(4 \times 8 \mathrm{~cm} ; 4 \times 12 \mathrm{~cm}$. etc. $)$. Income from fines and sales of confiscated products amounted to about $\$ 5700$ (2, 840, $000 \mathrm{XAF})$, representing about $67 \%$ of total income from about $655 \mathrm{~m}^{3}$ of legal logging from the Bimbia forest. These numbers are explained by easy accessibility to the Bimbia forest, which is located a few kilometres from Limbe town.

The Tinto community had agreed to exploit $2000 \mathrm{~m}^{3}$ of timber annually from the forest. But in three years nothing has happened. They advance the absence of an access road and lack of start-up resources as reasons for the inertia. Negotiations for timber exploitation are ongoing. The above evidence suggests many potential inadequacies regarding rules compliance for carbon forestry.

\section{Actor Relations}

Good actor relationships are necessary for success in carbon forestry. Figure 2 presents the state of relationships between the actors in the Tinto and Bimbia communities. The figure was developed mainly from interviews and secondary data, and discussed and validated with other actors especially those not interviewed.

Varied land tenure perceptions have affected the actor relationships in community forestry implementation in Bimbia. In Bimbia, it was agreed with the representatives of all actors during the land use plan and the simple management plan phases that each farmer within the forest would pay a registration fee of
2000FCFA (\$3.5), after which his or her farm would be assessed and annual rents determined. Less than 100 of the estimated 1000 farmers have registered. Farmers think registration is only a pretext and that rents might eventually be prohibitive, thereby kicking them out. They emphasise that the spirit of pre-community forest indigenous organisations such as the Victoria Lands and Forest Conservation and the Victoria Area Rainforest Common Initiative Group that aimed at ejecting "non-native usurpers" from their forest still prevails. Such land tenure perceptions and issues of trust explain the poor relationships between the management council and farmers or fuel wood collectors (Fig. 2) especially because many users of the forest are non-native.

Relations between communities and government can influence community project development and risk management in terms of enabling training and improving access to resources and technology. It could also stifle progress when conflicts arise in their relationship.

Community forestry policy stipulates that the Ministry of Forests and Fauna (MINFOF) is supposed to provide technical support to communities in forestry activities, but working relationships have been poor in both cases. Poor working relationships arise partly from lack of clarity in roles and responsibilities. The Bimbia community accuses MINFOF of illegally issuing about 14 logging permits within their forest, and lack of transparency with auction sale dues from joint seizures. MINFOF says Bimbia has no right to sanction defaulters while Bimbia insists the law allows them to deal with minor offences. The line between major and minor is not clear even for the neutral interpreter of policy. These examples of disagreements have created conflicts between the community and forest administration staff (see Fig. 2).

It is clear that communities will need external assistance with complex carbon measurement and monitoring tasks such as the use of allometric equa-
Fig. 2 Sociogram showing community forest actor relationships in both communities
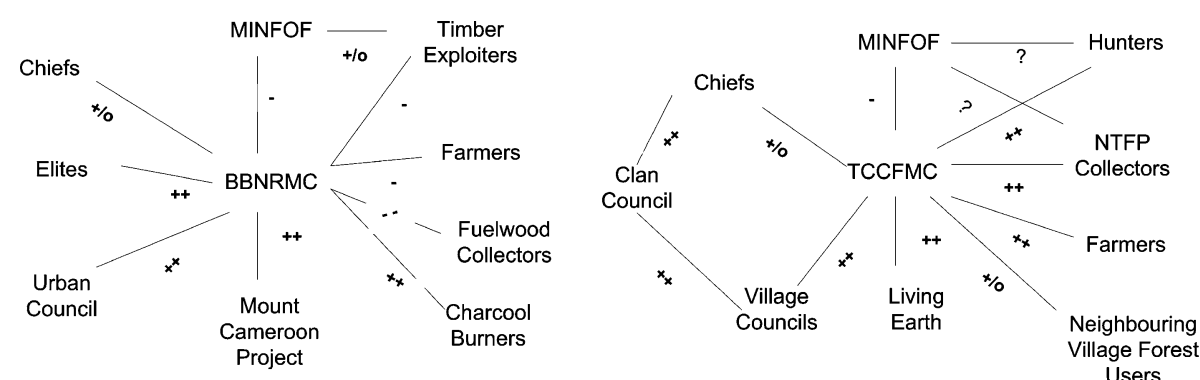

Bimbia Bonadikombo

$$
\text { Community }
$$

Key: | ++ $\begin{gathered}\text { Good } \\ \text { Relations | + }\end{gathered}$
Fair- No trust

Poor Relations |
Tinto Community

Do not tolerate each other 
tions, soil laboratory measurements, access to remote sensing technology, and information management. This would be expected from MINFOF, but the question is whether this government body is in a position to provide such assistance. To start with, technological knowhow and resources are in short supply in this government department. Existing allometric equations were developed for known marketable timber species only. Available and useful remote sensing and GIS data are limited to 1950 and 1991 aerial photographs covering some forest areas in the country. These could be used as evidence for land use and land cover for critical date requirements for CDM, i.e., December 31, 1989, for example. Staff and resources in the ministry are inadequate for supporting communities (Ekoko 2000). The ratio of staff to forest area in the southwest province, in which both Tinto and Bimbia are located, is about 1:15000ha. A senior forestry official acknowledged that they are so badly equipped that they sometimes ask for transportation or material support from communities in the fulfilment of their tasks. Staffs in most cases have little knowledge of carbon issues.

Relations between communities and NGOs have been good. NGOs or bilateral projects have provided the support communities' need for forest management. For example, in Bimbia, Mount Cameroon Project (GTZ-DFID funded) facilitated workshops on community forestry regulations and helped with the establishment of the legal entity. It also financed hired expertise for the training of community members and subsequent implementation of mapping, forest inventories, and the development of simple management plans. Living Earth Foundation used a similar approach in the case of Tinto. This support by NGOs continued through the entire community forestryplanning process and the early stages of implementation (late 2003 to early 2004).

But very often these NGOs have been using overseas development assistance funds. Such funds may not be acceptable under the CDM given the financial additionality criterion. This makes a compelling argument for the creation of a national fund to support CDM project development.

A summary of the findings is presented in Table 5. While the synthesis shows that communities have benefited in terms of income, knowledge, and skills acquisition and employment, it also reveals serious inadequacies in human, financial, and technological resources required for successful community forestry implementation. In comparative terms, Bimbia fared better with regards to resources. Perhaps Tinto's remote location and relatively smaller size explains the difference in resource availability.
Regarding management capability and conditions, a mix of similarities and differences can be noted. In similarities, both communities have received NGO support and have also had conflicts with forest administration on various issues. In differences, Bimbia has experienced substantial internal conflicts, high levels of illegal activity, forest degradation, and staff corruption. In Tinto, the forest has remained intact due to the absence of activities, owing mainly to the remoteness of the area, and lack of startup resources and entrepreneurship. These differences illustrate that local community capacity is a result of the unique manner in which these attributes coalesce in particular places and, therefore, should also be seen to a very large extent on a case-by-case basis (Agrawal 2001; Armitage 2005).

\section{Conclusions and Practical Implications}

Several studies have supported payment for environmental services within the commons as an emerging model of sustainable development for poor communities. Yet community capacity to implement such models often falls short of expectations. This paper set out to assess the capacity of communities to implement CDM projects in Cameroon. From experiences of success and failure in community forest implementation, we draw conclusions on the implications for $\mathrm{CDM}$ implementation within community forestry setups, i.e., in the case where communities currently managing forests decide to add on carbon sequestration as another land use.

Analysing the dimensions and determinants of community capacity for CDM in both the Bimbia and Tinto cases points to substantial inadequacies. It indicates that taking up CDM carbon management procedures complicates the challenges of local communities already grappling with huge community forest management difficulties within host country modalities and procedures. The inadequacies revealed serve as good arguments for varying dimensions of additionality in the CDM certification process. But more importantly however, evidence from the Bimbia and Tinto cases, though limited, also points to a number of generalizable observations on community capacity to manage terrestrial CDM projects.

Firstly, proactive capacity-building measures are needed to increase project uptake in poor countries. Our case studies highlight evidence that local communities lack the knowledge, skills, and technical and financial resources to accommodate current CDM rules. Management capabilities and conditions are also deficient in many ways. Tasks for baseline estimation, 
investment, financial, environmental and social impact, and leakage analysis cannot be met under poor community conditions in Cameroon and many parts of sub-Saharan Africa. This evidence supports previous explanations for why Africa is lagging behind in CDM project development, i.e., currently accounting only for $1.7 \%$ of all projects in the CDM pipeline (Desanker 2005). This raises serious questions about the potential of CDM contributing to sustainable development in its current form.

Due attention should, therefore, be given to multiple partnership arrangements and most especially to NGO capacity for supporting CDM implementation processes (Nelson and de Jong 2003). The Bimbia and Tinto cases point to the potential role NGOs can play in enabling project uptake and development. However, any community capacity approach for CDM needs to carefully consider tasks to be undertaken by communities and those to be undertaken by external agencies or consultants. This is because NGOs or consultants are developing many energy projects within the CDM and in some cases they get paid a proportion of the anticipated credits. Replicating such a scenario in CDM forestry could mean ignoring local competencies, thereby diverting vital community benefits in the form of credits. Sharing such roles and responsibilities especially vis-à-vis project developers and other partners could help reduce conflicts and facilitate institutional relations and hence resource governance. This could be beneficial for the development of other environmental services systems for water catchments or biodiversity.

Secondly, managing actor relationships as influenced by their motivations, perceptions, and resources, within multiple use forestry projects, is a great challenge regarding risk of project failure, leakage, and costs of CDM projects. Involving actors in building consensus and compliance is difficult and costly for local communities (de Jong and others 2000; Smith and Scherr 2003). The knowledge and facilitation skills required are enormous, therefore taking on carbon as another community forestland use will compound the knowledge and skills demands. Such evidence should support the prioritization of institutional capacity building for developing countries called for in Decision FCCC/CP/ 2004/L.11, and other documents within the Subsidiary Body for Implementation capacity building framework of the Kyoto Protocol.

Thirdly, this research brings a number of cross-scale $\mathrm{CDM}$ issues to the fore. It shows that community capacity depends on and is part of a forest/land use policy framework. The CDM framework assumes that the necessary macro-institutional and regulatory sup- port for micro-level implementation would be available. This study found out that neither sustainable development criteria nor supportive institutions and personnel exist in Cameroon.

Developing national CDM guidelines for both forestry and energy projects might be a necessary (but not sufficient) condition for CDM project development at a local level. It can be beneficial in providing institutional structure and for specifying critical standards on impact assessment, monitoring, measures preventing risk of project failure, and information management for CDM forestry projects. This supports earlier contentions that some regulation may be required to reduce livelihood risks and increase social benefits (Smith and others 2003; Minang and others 2007)

Supporting Designated National Authorities and allied ministerial services to provide proactive capacity building to poor communities is imperative for Kyoto Protocol processes if CDM is to succeed. This could help provide badly needed support from government institutions in the areas of resource/incentive provision, training, information management, monitoring, and marketing. Costa Rica is an example of a non-annex 1 country that has instituted proactive measures of this kind (FAO 2004; Subak 2000). An opportunity exists for the creation of a national fund to support CDM projects to help provide startup funds for communities in Cameroon. Such a fund could tap from the coffers of the Special Forestry Development Fund, a mechanism that enables a proportion of forestry tax revenues to be reinvested into forestry development. Putting such funds into capacity building and not project implementation could be justifiable under the CDM.

Finally, there is a need for a rethinking of current CDM forestry modalities. Current rules are complex, unfeasible, and unfairly beyond the capacity of poor communities such as those assessed in this study, thus confirming previous conclusions in Brown and others (2000) and Poffenberger and others (2002). It may also explain (at least in part) why India, China, Brazil, and Mexico combined hosted $83 \%$ of all CDM projects, while Africa hosted only $2 \%$ by June 2006 . Provisions for small-scale CDM forestry projects are not farreaching enough. They do not currently consider basic environmental and social impact and community negotiations costs, but our research demonstrates that they pose equally strong challenges to CDM project development even in instances where less than the small-scale threshold mitigation value of $8 \mathrm{kt} \mathrm{C} \mathrm{y}^{-1}$ applies. If the sustainable development objectives of the CDM and the Kyoto Protocol must be attained in the poorest countries, further consideration should be given to CDM modalities in the ongoing post-2012 
forestry negotiations. This study and others provide a growing body of evidence on community capacity for carbon forestry that could help in the development of more realistic and equitable CDM rules.

Acknowledgments We are grateful to the Directorate General for Development Cooperation of the Ministry of Foreign Affairs (DGIS) and International Institute for GeoInformation Science and Earth Observation (ITC), The Netherlands, for providing the funding and facilities that enabled this study. Many thanks to Margaret Skutsch at the University of Twente and three anonymous reviewers for valuable comments on earlier drafts of this paper.

\section{References}

Agrawal A (2001) Common property institutions and sustainable governance of resources. World Development 29:1649-1672

Armitage D (2005) Adaptive Capacity and Community-Based Natural Resource Management. Environmental Management 35:703-715

Asquith NM, Vargas MTR, Smith J (2002) Can forest-protection carbon projects improve rural livelihoods? Analysis of the Noel Kempff Mercado Climate Action Project, Bolivia. Mitigation and Adaptation Strategies for Global Change 7:323-337

Barrett CB, Lee DR, McPeaK JG (2005) Institutional arrangements for rural poverty reduction and resource conservation. World Development 33:193-197

Brown S, Masera O, Sathaye J, Andrasko K, Brown P, Frumhoff R, Lasco G, Leach G, Moura-Costa S, Mwakifwamba G, Phillips P, Read P, Sudha P, Tipper A, Riedacker A, Pinard M, Stuart M, Wilson C, Trexler M (2000) Project-Based Activities. In: Watson RT, Noble IR, Bolin B, Ravindranath NH, Verardo DJ, Dokken DJ (eds) Land Use, land-use change, and forestry. Cambridge University Press, Cambridge, UK

de Jong BHJ, Tipper R, Montoya-Gomez G (2000) An economic analysis of the potential for carbon sequestration by forests: evidence from southern Mexico. Ecological Economics 33:313-327

Desanker PV (2005) The Kyoto Protocol and the CDM in Africa: a good idea but. Unasylva 222(56):24-25

EcoSecurities (2002) Evaluation of the potential for developing a carbon programme in the Cameroon Mountains Region (Report for CAMCOF). Limbe, Cameroon

Ekoko F (2000) Balancing politics, economics and conservation: the case of the Cameroon Forestry Law reform. Development and Change 31:131-154

FAO (Food and Agriculture Organization) (2004) Climate Change and the Forest Sector. Possible national and subnational legislation. FAO Forestry Paper 144, FAO, Rome, Italy

FERN (Forests and the European Union Resource Network) (2000) Sinking the Kyoto Protocol. The Links between forests, plantations and carbon sinks. Moreton-in-Marsh, United Kingdom

Frankfort-Nachmias C, Nachmias D (1996) Research methods in the social sciences. 5th edn. St Martin' Press, New York

GEF (Global Environment Facility) (2000) Operational Program \#12 Integrated Ecosystem Management. Available at http://www.gefweb.org
Ivey JL, Smithers J, Loe RCD, Kreutzwiser RD (2004) Community capacity for adaptation to climate-induced water shortages: linking institutional complexity and local actors. Environmental Management 33:36-47.

Justice C, Wilkie D, Zhang Q, Brunner J, Donoghue C (2001) Central African forests, carbon and climate change. Climate Research 17:229-246

Klooster D, Masera O (2000) Community forest management in Mexico: carbon mitigation and biodiversity conservation through rural development. Global Environmental Change 10:259-272

Kotto-Same J, Woomer PL, Appolinaire M, Zefack L (1997) Carbon dynamics in slash-and-burn agriculture and land use alternatives of the humid forest zone in Cameroon. Agriculture, Ecosystem and Environment 65:245-256

Lee MK (2004) CDM Information and Guidebook. 2nd edn. United Nations Environment Programme, Roskilde, Denmark

Li TM (2002) Engaging simplifications: community-based resource management, market processes and state agendas in upland Southeast Asia. World Development 30:265-283

McCall MK, Minang PA (2005) Assessing participatory-GIS for community-based NRM: claiming community forests in Cameroon. The Geographical Journal 171:340-356

Minang PA, Bressers Th A, Skutsch MM, McCall MK (2007) National forest policy as a platform for biosphere carbon management: the case of community forestry in Cameroon Environmental Science and Policy (forthcoming)

MINEF (Ministry of Environment and Forests) (1998) Manual of Procedures for the Attribution, and Norms for the Management, of Community Forests. Yaounde, Cameroon

Nelson KC, de Jong BH (2003) Making global initiatives local realities: carbon mitigation projects in Chiapas, Mexico. Global Environmental Change 13:19-30

Pagiola S, Arcenas A, Platais G (2005) Can payments for environmental services help reduce poverty? An exploration of issues and the evidence to date from Latin America. World Development 33:237-253

Palm CA, Woomer PL, Allegre J, Arevelo L, Castilla C, Cordeiro DG, Feigel B, Hairiah K, Kotto-Same J, Mendes A, Moukam A, Murdiyarso D, Njomgang R, Parton WJ, Ricse A, Rodrigues V, Sitompul SM, van Noorwijk M (2000) Carbon sequestration and trace gas emissions in slash-and-burn and alternative land-uses in the humid tropics. Alternatives to Slash Burn (ASB) Climate Change Working Group Final Report, Phase II. World Agroforestry Centre, ICRAF. Nairobi

Poffenberger M, D'Silva E, Ravindranath NH, Pingle U, Murthy I, Tuttle A (2002) The clean development mechanism and village-based forest restoration. A case study from Adilabad District, Andhra Pradesh, India. Community Forestry International, Santa Barbara, California

RCDC (Regional Centre for Development and Conservation) (2002) The viable resource management model for participatory biodiversity conservation in the Bimbia Bonadikombo Area. Limbe, Cameroon

Santili M, Moutinho P, Schwartzman S, Nepstad D, Curran L, Nobre C, (2005) Tropical Deforestation and the Kyoto Protocol: An editorial essay. Climate Change 71:267-276

Smith J, Scherr SJ (2003) Capturing the value of forest carbon for local livelihoods. World Development 31:2143-2160

Subak S (2000) Forest Protection and Reforestation in Costa Rica: Evaluation of a clean development mechanism prototype. Environmental Management 26:283-297

White A, Martin A (2002) Who owns the world's forests? Forest Trends, Washington, D.C 
Yin RK (1994) Case study research: design and methods. SAGE Thousand Oaks, CA

Zahabu E (2006) Case Study: Handei Village Forest Reserve, Tanzania. In: Skutsch M (ed) Community Forest Manage- ment as a Carbon Mitigation Option. Rationale and Case Studies. Technology and Sustainable Development, University of Twente, The Netherlands 